\title{
OBSERVATIONS ON THE EXCRETION OF CALCIUM IN TWO CASES OF NEPHROSIS TREATED WITH PARATHYROID EXTRACT
}

\author{
BY W. DE M. SCRIVER, M.D. \\ (From the Department of Medicine, McGill University Clinic, Royal Victoria Hospital, \\ Montreal, Canada)
}

(Received for publication June 14, 1928)

The fact that in cases of nephrosis there is a marked decrease in the total plasma proteins, with inverted albumin globulin ratio and a high blood cholesterol, has become well recognized since the first publication of Epstein's (1) observations. However in the original communication and in the literature that has since appeared, there is practically no mention of the low serum calcium which prevails in these cases.

Numerous observations of low serum calcium values in nephritis have been made by various authors (2) (3) (4) (5) (6), but an analysis of the details of the cases on which these observations were made points to the conclusion that, with the possible exception of case 8 of Denis and Hobson (4), all were suffering from advanced chronic nephritis, in the uremic or pre-uremic state, and could not be classified as nephrosis. Salvesen and Linder (7) appear to be the first to draw attention to the low calcium associated with definite nephrosis, ascribing the low value to a decrease in the amount normally bound to the proteins.

Numerous attempts have been made to raise the serum calcium by the administration of calcium salts, both by mouth (5) (6) (7) (8) (9) (10), and by intravenous injection (11); the former has had varied success, the latter has given but transient rises. With the discovery by Collip (12) and others of the active principle of the parathyroid gland a new means was provided for raising the calcium level. Davidson (13) was the first to publish an account of its use in a case of nephrosis, in which he was able to restore the serum calcium to normal figures, with some improvement in the clinical symp- 
tomatology. Mason (14) reported similar results in a case of nephritis of the azotemic type. In another communication (15) three cases of chronic nephrosis treated with parathyroid extract are reported from the clinical viewpoint. The present communication concerns some observations on the calcium metabolism of two of these cases. A summary of the history of these patients is appended.

Case I. I. H., female, aged 4. Admitted in August, 1925, with general anasarca. No history of previous infections, and apparently well until three days before admission, when edema first appeared in the feet, rapidly extending to involve the whole body.

Physical examination. Marked general anasarca, tonsils enlarged, not inflamed. Sinuses negative. Heart not enlarged. Blood pressure 106/78. Liver just palpable beneath costal margin. Fundi normal. Urine-albumin 15 grams per liter, granular casts, leucocytes. Specific gravity 1014-1022. Blood nonprotein nitrogen $25 \mathrm{mgm}$. per $100 \mathrm{cc}$. Total protein 5.05 per cent. Albumin globulin ratio 1:3.2. Cholesterol $425 \mathrm{mgm}$. per $100 \mathrm{cc}$. Calcium $5.7 \mathrm{mgm}$. per 100 cc. Wassermann negative. Slight anemia.

At the time the present observations were made there had been no appreciable change in the general condition for some six months in spite of various therapeutic procedures.

Case II. R. F., male, age 20. Admitted in September, 1926, with general anasarca. Was unaware of any renal disease until September, 1925, when life insurance was refused because of albuminuria. No history of infections except "Grippe." Edema began in February, 1926, and had been increasing up to time of admission.

Physical examination. General anasarca, heart not enlarged. Vessels not sclerosed. Blood pressure 142/92. Fundi negative. Urine-albumin 11 grams per liter, hyaline and granular casts. Specific gravity varied from 1014-1018, nocturnal polyuria, specific gravity 1012 . Urea concentration 1.48 per cent. Factor 21.3 (MacLean). Blood urea nitrogen $20.7 \mathrm{mgm}$. per $100 \mathrm{cc}$. Calcium $8.7 \mathrm{mgm}$. per $100 \mathrm{cc}$. Blood proteins 5.49 per cent. Albumin globulin ratio 1:2. Cholesterol $500 \mathrm{mgm}$. per $100 \mathrm{cc}$. Basal metabolic rate-30.4 per cent. Wassermann negative.

\section{GENERAL METHODS}

Each patient was supplied a weighed diet of general nature, the composition of which remained unchanged during the whole course of the experimental period. In case I occasional portions of food not eaten at meal time were fed during the course of the day; in case II all the diet was eaten at meals. Under these conditions the 
daily intake of calcium should be approximately constant. No actual chemical determinations of the calcium content of the diet were made, but an approximate figure was arrived at by using values based on Sherman's tables (16).

Extra calcium was given by mouth in the form of calcium lactate. In case I the crushed 5-grain tablets of a common commercial make were given three times daily after meals. Analyses of several of these tablets showed that the calcium content of individual tablets was constant, but that the actual calcium content was lower than the theoretical content. The analytical figure has been used in computing the calcium intake. In view of this difficulty, in case II chemically pure calcium lactate was given in powder form after meals three times daily. During the course of experiments the fluid intake was kept constant in each case.

The parathyroid extract was given in doses of 50 units at 6 a.m. by subcutaneous injection into the arm.

\begin{tabular}{|c|c|}
\hline \multicolumn{2}{|c|}{ Diets for Case I } \\
\hline March 9th to 28th, inclusive & May 14th to June 2nd, inclusive \\
\hline $\begin{array}{l}\text { Approximate content of calcium- } \\
800 \mathrm{mgm} .\end{array}$ & $\begin{array}{c}\text { Approximate content of calcium- } \\
1025 \mathrm{mgm} .\end{array}$ \\
\hline Orange. .......... 200 grams & $\ldots \ldots \ldots 200$ grams \\
\hline$\ldots \ldots \ldots \ldots \ldots 550 \mathrm{cc}$ & Milk. ....... \\
\hline White bread......... 80 grams & White bread.......... 65 grams \\
\hline Butter............ 16 grams & Butter.............. \\
\hline Cooked oatmeal....... 200 grams & Boiled rice........... \\
\hline Egg.............. & Cornflakes. ........... \\
\hline Baked apple........ 150 grams & Roast chicken......... \\
\hline Baked banana........ 50 grams & $\begin{array}{l}\text { Baked potato......... } 100 \text { grams } \\
\text { Chopped carrots....... } 60 \text { grams } \\
\text { Cream cheese........ } 20 \text { grams } \\
\text { Raisins............ } 12 \text { grams }\end{array}$ \\
\hline \multicolumn{2}{|c|}{ Diet for Case II } \\
\hline \multicolumn{2}{|c|}{$\begin{array}{l}\text { October } 21 \text { st to November } 19 \text { th, inclusive } \\
\text { Approximate content of calcium-600 mgm. }\end{array}$} \\
\hline$\ldots \ldots \ldots \ldots 126$ grams & Roast chicken......... \\
\hline Butter...........83 grams & Egg........... 1 \\
\hline Sugar............. 28 grams & Orange. .......... 100 grams \\
\hline Canned corn $\ldots \ldots \ldots \ldots 100$ grams & Baked apple........ \\
\hline Canned tomatoes. ..... 100 grams & Canned cherries....... 100 grams \\
\hline Carrots........... 100 grams & Dates........... 31 grams \\
\hline ... 100 grams & Cream........... 100 cc. \\
\hline Lettuce............ 20 grams & Milk. ........... 100 cc. \\
\hline Tomato (fresh)........ 100 grams & 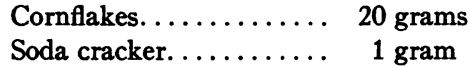 \\
\hline
\end{tabular}


The urine was collected under toluol in 24-hour amounts starting at 6 a.m.; the completeness of collection was checked by daily creatinine determinations. In case II these values were practically constant; in case I, where the daily values did not check, the daily averages for each complete period agreed closely. This was apparently due to the fact that owing to incomplete emptying of the bladder at the end of each 24-hour period, the collections for these periods were incomplete; however, when collections were extended over five days, this error became minimized and a daily average was arrived at.

At the beginning and end of each period 0.3 gram carmine was given by mouth at 6 a.m., and all stools from the first appearance of the dye up to the appearance of the second dose were collected and included in that period. The total resulting stool was evaporated on a water bath, dried to constant weight in an oven at $100^{\circ} \mathrm{C}$., ground to a fine powder, and thoroughly mixed; aliquot portions of this powder were taken for the various analyses.

Blood for calcium determination was drawn from the antecubital veins twelve hours after the administration of parathyroid extract, allowed to clot, and the serum separated as soon as possible by centrifugalization.

\section{CHEMICAL METHODS}

Calcium in the serum was estimated by Fiske's modification of Kramer and Tisdall's method (17). The calcium in the urine was determined on volumes of 25 cc., evaporated to dryness, ashed in the muffle furnace at faint red-heat, and made up to the original volume in solution in $0.1 \mathrm{~N} \mathrm{HCl}$. Ten cubic centimeters of this solution was measured into a centrifuge tube, $4 \mathrm{cc}$. of saturated solution of ammonium oxalate added, and the reaction then adjusted to the turning point of methyl red (approximately $\mathrm{pH} 5$ ) by the addition of ammonium hydroxide. The procedure was then carried out as for the serum.

In the case of the stools, 1 gram of finely powdered dried feces was ashed and made up to $100 \mathrm{cc}$. volume similarly to the urine. The calcium in aliquot parts of this solution was then determined as above.

All ashings and precipitations were carried out in duplicate, and only results which checked were accepted.

\section{DISCUSSION}

The most striking feature is the extremely small amount of calcium excreted during the control period in the urine of these patients, 
compared with the amount reported for normal subjects by various authors (see table 2). Nor does the administration of parathyroid

TABLE 1

Average daily calcium excretion in nephrosis patients

\begin{tabular}{|c|c|c|c|c|c|c|c|c|c|}
\hline \multirow[b]{2}{*}{$\begin{array}{c}\text { Case } \\
\text { number }\end{array}$} & \multirow[b]{2}{*}{$\begin{array}{c}\text { Dates } \\
\text { (inclusive) }\end{array}$} & \multirow{2}{*}{$\begin{array}{c}\text { Para- } \\
\text { thyroid } \\
\text { units } \\
\text { daily }\end{array}$} & \multicolumn{2}{|c|}{ Intake } & \multicolumn{3}{|c|}{ Output } & \multicolumn{2}{|c|}{ Serum } \\
\hline & & & $\begin{array}{c}\text { Food } \\
\text { (approxi- } \\
\text { mate } \\
\text { estimate) }\end{array}$ & $\begin{array}{c}\text { As } \\
\text { calcium } \\
\text { lactate }\end{array}$ & Urine & Feces & Total & $\begin{array}{l}\text { Maxi- } \\
\text { mum }\end{array}$ & $\begin{array}{l}\text { Mini- } \\
\text { mum }\end{array}$ \\
\hline \multirow{7}{*}{ I } & & mnits & mgm. & mgm. & mem. & mgm. & $m g m$. & $\begin{array}{c}\text { mgm. } \\
\text { per } \\
100 \text { ce. }\end{array}$ & $\begin{array}{c}\text { mgm. } \\
\text { per } \\
100 \mathrm{cc} .\end{array}$ \\
\hline & March 9-14 & & 810 & & 2.01 & 600 & 602 & \multicolumn{2}{|c|}{5.7} \\
\hline & March 15-21 & 40 & 810 & & 2.15 & 647 & 649 & 6.6 & 6.1 \\
\hline & March 22-28 & 50 & 810 & 661 & 8.45 & 986 & 994 & 8.2 & 6.8 \\
\hline & May 14-20 & & 1,025 & 661 & 2.40 & 655 & 657 & \multicolumn{2}{|c|}{8.4} \\
\hline & May 22-27 & & 1,025 & & 2.75 & 383 & 386 & \multicolumn{2}{|c|}{6.3} \\
\hline & May 27-June 2 & 50 & 1,025 & & 2.86 & 525 & 528 & 7.0 & 6.1 \\
\hline \multirow{5}{*}{ II } & October 21-25 & & 600 & & 10.0 & 359 & 369 & \multicolumn{2}{|c|}{7.3} \\
\hline & October $26-30$ & 50 & 600 & & 10.8 & 441 & 452 & 10.2 & 8.5 \\
\hline & November 2- 6 & & 600 & 1,101 & 6.3 & 967 & 973 & 8.5 & 7.3 \\
\hline & November $7-11$ & 50 & 600 & 1,101 & 5.0 & 1,149 & 1,154 & 10.2 & 7.4 \\
\hline & November $11-14$ & & 600 & & 5.7 & 434 & 440 & \multicolumn{2}{|c|}{7.5} \\
\hline
\end{tabular}

TABLE 2

Daily calcium excretion in urine of normal and pathological subjects as found in the literature

\begin{tabular}{|c|c|c|c|}
\hline Author & Subject & $\begin{array}{l}\text { Approximate } \\
\text { daily calcium } \\
\text { intake }\end{array}$ & $\begin{array}{l}\text { Approxi- } \\
\text { mate daily } \\
\text { calcium } \\
\text { excretion } \\
\text { in urine }\end{array}$ \\
\hline & & msm. & mgm. \\
\hline Sherman (18)............... & Normal male adults & $180-460$ & $110-360$ \\
\hline Hunter and Aub (19).......... & Adults-lead poisoning & $500-1,000$ & $33-166$ \\
\hline Bergeim et al. (20). . . . . . . . . & Acromegalic adult & 1,070 & 114 \\
\hline Sherman and Hawley (21)....... & Normal childrẹn 3-4 years & $400-1,700$ & $10-50$ \\
\hline Boyd et al. (22)............... & Normal children & Milk diet & $80-220$ \\
\hline Bergeim et al. (23). ........ & $\begin{array}{l}\text { Thyroparathyroidecto- } \\
\text { mized adult }\end{array}$ & 1,200 & $9.3^{\circ}$ \\
\hline Boyd et al. (22).......... & $\begin{array}{l}\text { Children with nephritis } \\
\text { and nephrosis }\end{array}$ & Milk diet & 30 \\
\hline
\end{tabular}

extract appear to have any noticeable effect in altering this excretion, except in the one period in case $I$, where, when parathyroid extract 
and calcium lactate were given together, there was a definite increase approaching the minimum value found by Sherman (21) in normal children of similar age. A like effect, however, was not obtained in case II, an adult.

In the low urinary excretion of calcium these subjects resemble the subject of Bergeim, Stewart and Hawk (23), who after thyroparathyroidectomy, showed an average daily output of $9.3 \mathrm{mgm}$. in the urine. A similarly reduced excretion in children suffering from nephritis and from nephrosis has been reported by Boyd, Courtney and MacLachlan (22), and in several nephritics, apparently in uremic states, by Halverson, Mohler, and Bergeim (5).

In this connection the observations of Hetényi and Nógrádi (24) are of interest. These authors found that after the intravenous injection of calcium salts, the excretion in the urine of nephritic subjects was much less than in normal controls; their subjects, however, like those of Halverson, appear to have been of the azotemic, rather than the nephrotic, type.

On the other hand, Hunter and Aub (19) have shown that in cases of lead poisoning, with presumably normal renal function, there was a marked increase in the calcium excreted in the urine when parathyroid extract was administered, the increase averaging 83 per cent above that of the control period. Greenwald and Gross (25) have demonstrated that dogs receiving daily doses of parathyroid extract showed a marked increase in calcium excretion, the greatest increase being in the urine, and to a lesser extent in the stool. These various investigators used, over long periods of time, doses of approximately the same average size as those used in our subjects, and the increased excretion in the urine began almost simultaneously with the administration of parathyroid extract. Our case I, a child weighing $17 \mathrm{kgm}$., including edema, received 50 units of Collip's extract daily, actually a much larger dose per kilogram of body weight than that administered in the cases of lead poisoning.

It would therefore seem probable that in these cases of nephrosis there is a definite impairment of the ability of the kidney to excrete calcium, an impairment which is not overcome by the use of parathyroid extract, even when the level of calcium in the blood is raised to the normal. 
In contrast to the extremely small excretion of calcium in the urine, that in the stool was relatively large, and accounted for practically the whole of the total excreted, so much so that the excretory side of the calcium balance in this type of case might almost be determined from stool alone. Under parathyroid therapy there was a definite increase in the calcium excretion in the feces, in one case as much as 37 per cent greater than the control period.

As might be expected, the addition of extra calcium to the diet (in the form of calcium lactate) caused an increased excretion in the stool; however, in neither case was this increased excretion as great as the increased intake, so that definite retention and absorption apparently took place. When parathyroid extract was administered with the extra calcium lactate, the highest values for fecal calcium were obtained, though again the total increase over the control period was less than the increased intake. It is thus evident that the addition of these moderately large doses of calcium lactate was more than sufficient to counteract the loss caused by the parathyroid extract over the short periods of observation ( 5 to 6 days). In case II, during the period immediately following the discontinuance of both the forms of therapy, a lag effect was evident in the excretion in the feces, the values being almost as high as during the period of administration of parathyroid extract alone. This effect is similar to that reported by Hunter and Aub (19) in lead poisoning.

The effect of the various forms of therapy on the serum calcium varied in the two cases. In the first, where the calcium was markedly lowered $(5.7 \mathrm{mgm}$. per $100 \mathrm{cc}$.), in spite of relatively large doses of parathyroid extract, normal figures were not reached, the highest being $6.8 \mathrm{mgm}$. per $100 \mathrm{cc}$. When calcium lactate was added to the diet while the extract was continued, this figure reached $8.2 \mathrm{mgm}$. per $100 \mathrm{cc}$. The highest value obtained, 8.4, was after the patient had been receiving extra calcium lactate, but no parathyroid extract, for some six weeks; on its discontinuance, the value fell again to a lower level. In the relative failure to react to parathyroid extract this case resembles the fourth case of Hunter and Aub (19), which showed a similar increased excretion in the feces, with no appreciable rise in the serum calcium.

In the second case, where the serum calcium was not quite so low, 
the normal level of $10.2 \mathrm{mgm}$. per cubic centimeter was reached after several days of parathyroid extract therapy; this was not maintained during the short course of calcium lactate alone which followed it, but when the extract was again administered, along with the extra calcium lactate, the same normal level was reached, to fall again with the discontinuance of all therapy.

It is possibly of significance that in both cases increases in the serum calcium were associated with increased excretion in the feces.

\section{COMMENT}

In view of the recent studies of Aub and Bauer (26), who have shown that in myxedema the excretion of calcium is less than in the normal individual, whereas in hyperthyroid states it is greater, it is of interest to note that in both of these patients the basal metabolic rate was much below normal ( -20 to -30 per cent), a typical finding in nephrosis first pointed out by Epstein (27). It is possible that their low calcium excretion is due to a mechanism similar to that acting in the myxedema cases of Aub and Bauer (26). Unfortunately no studies of calcium excretion were made while these patients were under thyroid therapy.

On the other hand, the observations of Greenwald and Gross (28) have shown that, in dogs, after the removal of the parathyroid glands along with the thyroid, there is a marked decrease in the excretion of calcium, rendering easy the maintenance of a positive balance; a low serum calcium is also a marked feature. When parathyroid extract is given, however, these animals again resume a normal excretion.

Though no actual determination was made of the calcium in the diet, yet if it be estimated even approximately according to Sherman's tables (16) it would appear that these patients with their low calcium excretion were always in positive calcium balance. When the parathyroid extract was given, however, the excretion was increased, tending to decrease the positive balance. The administration of moderately large doses of calcium lactate by mouth was more than sufficient to balance the increased excretion produced by the parathyroid extract.

It is possible that it is a combined thyroid and parathyroid in- 
sufficiency which influences the low level of excretion in the urine. In this respect it may be of significance that the lowest figures found in the literature for urine calcium are in the case studied by Bergeim (23) after thyroparathyroidectomy, where the daily excretion reached the low level of $9.3 \mathrm{mgm}$., a value similar to that found in our second case.

\section{CONCLUSIONS}

In two cases of chronic nephrosis the excretion of calcium in the urine was found to be extremely small. The administration of parathyroid extract had practically no effect on the calcium of the urine, but caused a marked increase in that of the feces. The period of increased excretion corresponded with increase of an already low calcium in the serum.

The calcium excretion of these cases appears to be similar to that observed by Hunter and Aub (19) in cases of myxedema, and by Bergeim (23) in a case of thyroparathyroidectomy.

It required relatively large doses of parathyroid extract to increase the serum calcium values; in one case these were still below normal in spite of large doses of a proved potent extract.

Thanks are due to Dr. Collip for supplying a quantity of parathyroid extract which he had prepared himself.

\section{BIBLIOGRAPHY}

1. Epstein, A. A., Am. Jour. Med. Sci., 1917, cliv, 638. Concerning the Causation of Edema in Chronic Parenchymatous Nephritis; Method for Its Alleviation.

2. Marriott, W.McK., and Howland, J., Jour. Biol. Chem., 1917, xxxii, 233. A Micro Method for the Determination of Calcium and Magnesium in Blood Serum.

3. Kramer, B., and Tisdall, F. F., Jour. Biol. Chem., 1921, xlvii, 475. A Simple Technique for the Determination of Calcium and Magnesium in Small Amounts of Serum.

4. Denis, W., and Hobson, S., Jour. Biol. Chem., 1923, lv, 183. A Study of the · Inorganic Constituents of the Blood Serum in Nephritis.

5. Halverson, J. O., Mohler, H. K., and Bergeim, O., Jour. Biol. Chem., 1917, xxxii, 171. The Calcium Content of the Blood Serum in Certain Pathological Conditions.

6. Denis, W., and Minot, A. S., Jour. Biol. Chem., 1920, xli, 357. Effects of Feeding with Calcium Salts on the Calcium Content of the Blood. 
7. Salvesen, H. A., and Linder, G. C., Jour. Biol. Chem., 1924, lviii, 617. Observations on the Inorganic Bases and Phosphates in Relation to the Protein of Blood and other Body Fluids in Bright's Disease and in Heart Failure.

8. Mason, E. H., Jour. Biol. Chem., 1921, xlvii, 3. A Note on the Absorption of Calcium Salts in Man.

9. Percival, G. H., and Stewart, C. P., Quart. Jour. Med., 1926, xix, 235. Pathological Variations in the Serum Calcium.

10. Keith, N. M., Barrier, C. W., and Whelan, M., Jour. Amer. Med. Assoc., 1924, lxxxiii, 666. Treatment of Nephritis and Edema with Calcium.

11. Salvesen, H. A., Hastings, A. B., and MacIntosh, J., Jour. Biol. Chem., 1924, 1x, 327. The Effect of the Administration of Calcium Salts on the Inorganic Composition of the Blood.

12. Collip, J. B., Jour. Biol. Chem., 1925, lxiii, 395. The Extraction of a Parathyroid Hormone which will Prevent or Control Parathyroid Tetany, and which Regulates the Level of Blood Calcium.

13. Davidson, J. R., Can. Med. Assoc. Jour., 1925, xv, 803. A Case of Adolescent Myxoedema Accompanied by Nephrosis and by Tetany of Parathyroid Origin Treated with Thyroid and Collip's Parathyroid Extract.

14. Mason, E. H., Can. Med. Assoc. Jour., 1926, xvi, 538. A Case of Chronic Nephritis Treated with Collip's Parathyroid Extract.

15. Lewis, D. S., and Scriver, W. de M., Annals of Int. Med., (in press). The Response of Chronic Nephrosis to Parathyroid and Thyroid Medication.

16. Sherman, H. C., 1924, Chemistry of Food and Nutrition, Macmillan \& Co., p. 421.

17. Hamilton, Bengt, Jour. Biol. Chem., 1925, lxv, 101. A Comparison of the Concentration of Inorganic Substances in Serum and Spinal Fluid.

18. Sherman, H. C., Jour. Biol. Chem., 1920, xliv, 21. Calcium Requirement of Maintenance in Man.

19. Hunter, D., and Aub, J. C., Quart. Jour. Med., 1927, xx, 123. Lead Studies. XV. The Effect of the Parathyroid Hormone on the Excretion of Lead and of Calcium in Patients Suffering from Lead Poisoning.

20. Bergeim, O., Stewart, F. T., and Hawk, P. B., Jour. Exper. Med., 1914, xx, 225. Calcium Metabolism after Thyroparathyroidectomy.

21. Sherman, H. C., and Hawley, E., Jour. Biol. Chem., 1922, liii, 375 . Calcium and Phosphorus Metabolism in Childhood.

22. Boyd, G. L., Courtney, A. M., and MacLachlan, I. F., Amer. Jour. Dis. Child., 1926, xxxii, 29. The Metabolism of Salts in Nephritis. I. Calcium and Phosphorus.

23. Bergeim, O., Stewart, F. T., and Hawk, P. B., Jour. Exper. Med., 1914, xx, 218. A Study of the Metabolism of Calcium, Magnesium, Sulphur, Phosphorus, and Nitrogen in Acromegaly.

24. Hetényi, G., and v. Nógrádi, S., Klin. Wchnschr., 1925, iv, 1308. Ưber die Kalkausscheidung der gesunden und kranken Niere. 
25. Greenwald, I., and Gross, J., Jour. Biol. Chem., 1925, lxvi, 217. The Effect of the Administration of a Potent Parathyroid Extract upon the Excretion of Nitrogen, Phosphorus, Calcium, and Magnesium, with some Remarks on the Solubility of Calcium Phosphate in Serum and on the Pathogenesis of Tetany. Jour. Biol. Chem., 1926, lxviii, 325. The Effect of Long Continued Administration of Parathyroid Extract upon the Excretion of Phosphorus and Calcium.

26. Aub, J. C., Bauer, W., Ropes, M., and Heath, C., Trans. Assoc. Amer. Phys., 1927, xlii, 344. The Relation of the Thyroid Gland to Calcium Metabolism.

27. Epstein, A. A., and Lande, H., Arch. Int. Med., 1922, xxx, 563. Studies on Blood Lipoids. I. The Relation of Cholesterol and Protein Deficiency to Basal Metabolism.

28. Greenwald, I., and Gross, J., Jour. Biol. Chem., 1925, lxvi, 185. The Effect of Thyroparathyroidectomy in Dogs upon the Excretion of Calcium, Phosphorus and Magnesium. 